medRxiv preprint doi: https://doi.org/10.1101/2021.09.13.21262182; this version posted September 24, 2021. The copyright holder for this preprint (which was not certified by peer review) is the author/funder, who has granted medRxiv a license to display the preprint in perpetuity.

It is made available under a CC-BY-ND 4.0 International license .

\title{
mRNA COVID-19 Vaccination and Development of CMR-confirmed Myopericarditis
}

Tahir Kafil, Mariana M Lamacie, Sophie Chenier, Heather Taggart, Nina Ghosh, Alexander Dick, Gary Small, Peter Liu, Rob S Beanlands, Lisa Mielniczuk, David Birnie and Andrew M Crean

During the process of open peer review on MedRxiv we quickly received a number of messages from reviewers concerned that there was a problem with our reported incidence of myocarditis post mRNA vaccination. Our reported incidence appeared vastly inflated by an incorrectly small denominator (ie number of doses administered over the time period of the study). We reviewed the data available at Open Ottawa and found that there had indeed been a major underestimation, with the actual number of administered doses being more than 800,000 (much higher than quoted in the paper).

In order to avoid misleading either colleagues or the general public and press, we the authors unanimously wish to withdraw this paper on the grounds of incorrect incidence data. We thank the many peer reviewers who went out of their way to contact us and point out our error. We apologize to anyone who may have been upset or disturbed by our report.

In summary, the authors have withdrawn this manuscript because of a major error pertaining to the quoted incidence data. Therefore, the authors do not wish this work to be cited as reference for the project. If you have any questions, please contact the corresponding author. 